\title{
Preparation and Properties of Alumina Coatings as Tritium Permeation Barrier by Plasma Electrolytic Oxidation
}

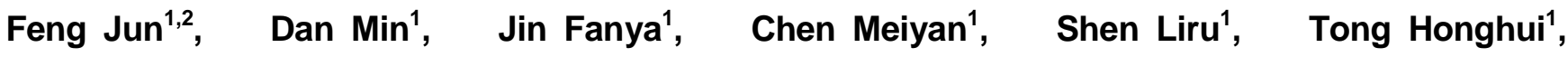 \\ Zhang Guikai ${ }^{3}$
}

${ }^{1}$ Southwestern Institute of Physics, Chengdu 610041, China; ${ }^{2}$ University of South China, Hengyang 421001, China; ${ }^{3}$ China Academy of Engineering of Physics, Mianyang 621907, China

\begin{abstract}
The alumina coatings as tritium permeation barrier were deposited on $316 \mathrm{~L}$ stainless steel substrates by plasma electrolytic oxidation. The effects of plasma electrolytic oxidation on the coatings were investigated, and phase, surface morphology and thickness were characterized by XRD, SEM and eddy current method, respectively. After scratch adhesion test, thermal shock resistance test and tritium permeability test, the optimized coatings were obtained. The results show that the phase, the surface morphology and the thickness are affected by current density, voltage and PEO (plasma electrolytic oxidation) duration time. The current density and voltage can change the phase structure of coatings, higher current density propels the transformation of $\mathrm{Al} \rightarrow \mathrm{Al}_{2} \mathrm{O}_{3}$ and higher voltage propels the transformation of $\gamma-\mathrm{Al}_{2} \mathrm{O}_{3} \rightarrow \alpha-\mathrm{Al}_{2} \mathrm{O}_{3}$. With increasing voltage and duration time, the pore size becomes bigger and the quantity is less so that the surface morphology is worse. With current density increasing to appropriate value $\left(9 \mathrm{~A} / \mathrm{dm}^{2}\right)$, surface morphology becomes good. After a series of tests, the coatings, which are obtained at $6 \mathrm{~A} / \mathrm{dm}^{2}, 300 \mathrm{~V}, 30$ min, exhibit good performances with good film-substrate cohesion, thermal shock resistance, and the tritium permeation resistance of coated sample is improved by 3 orders of magnitude higher than that of the $316 \mathrm{~L}$ stainless steel bulk.
\end{abstract}

Key words: alumina coatings; tritium permeation barrier; plasma electrolytic oxidation (PEO)

Tritium is the important nuclear material and widely used in the nuclear field. Because tritium has high permeability and toxicity, its permeation not only causes nuclear pollution, but also wastes large sums of raw materials. Tritium permeation resistance always is an important issue in the nuclear field ${ }^{[1]}$. The preparation of ceramic coatings on structure materials with low diffusivity (so-called penetration barriers) seems to be a better practical method to reduce or hinder the permeation of tritium through the substrates. The preparation of alumina coatings as tritium permeation barrier on stainless steel substrate is one of the research focuses, because alumina coatings have the following characteristics: the permeation reduction factor (PRF) is high where PRF is ratio of deuterium permeability of uncoated sample to deuterium permeability of coated sample; meanwhile alumina coatings have the ability of self-repairing as the active $\mathrm{Al}$ atom can capture $\mathrm{O}$ atom and then the coatings coexisting with their cracks, are repaired ${ }^{[2,3]}$.

There are many preparation methods of alumina coatings as tritium permeation barrier, including magnetron sputtering, chemical vapor deposition, ionic liquid electroplating-high temperature oxidation, double glow plasma surface alloying technique, etc ${ }^{[4-7]}$. Through the methods presented above, the PRF of alumina coatings as

Received date: February 08, 2015

Foundation item: International Thermonuclear Experimental Reactor Foundation of China (2013GB110006); National Natural Science Foundation of China (11305054, 11305055)

Corresponding author: Feng Jun, Candidate for Ph. D., Southwestern Institute of Physics, Chengdu 610041, P. R. China, Tel: 0086-28-82820988, E-mail: speedfjkang@163.com

Copyright $\odot$ 2016, Northwest Institute for Nonferrous Metal Research. Published by Elsevier BV. All rights reserved. 
tritium permeation barrier is usual low, and the reasons are as follows: 1) the worse film-substrate cohesion causes alumina coatings failure; 2) the coating thickness is thin (below $1 \mu \mathrm{m}$ ); 3) the low tritium permeability $\alpha-\mathrm{Al}_{2} \mathrm{O}_{3}$ is not the dominant phase in the alumina coatings. As shown above, it is very crucial to obtain good film-substrate cohesion, thick and high $\alpha$ phase alumina containing coatings for the high tritium resistivity.

On the basis of recent developments, the alumina coatings obtained by plasma electrolytic oxidation, are thick and have good film-substrate cohesion with high $\alpha$ phase content, and $316 \mathrm{~L}$ stainless steel is an important structural material in nuclear fusion. It is worthy studying the alumina coatings obtained through plasma electrolytic oxidation on $316 \mathrm{~L}$ stainless steel substrate ${ }^{[8]}$.

The aim of the present investigation is to prepare a stainless steel substrate sample tightly coated with alumina by the plasma electrolytic oxidation technique. For this purpose, some important parameters of PEO (current density, voltage, duration time. etc.) influencing the properties of coated samples such as film-substrate cohesion, thermal shock resistance etc. were studies in detail.

\section{Experiment}

$316 \mathrm{~L}$ stainless steel samples with $30 \mathrm{~mm} \times 30 \mathrm{~mm} \times 5 \mathrm{~mm}$ dimension were polished with abrasive papers, degreased in acetone medium and thoroughly dried. The hot-dip aluminizing coatings with about $40 \mu \mathrm{m}$ thickness were prepared by two bath flux method on $316 \mathrm{~L}$ stainless steel substrates, and then the sample oxide films were cleaned in an aqueous solution of $\mathrm{HF}+\mathrm{HNO}_{3}$. After washing with acetone and pure water, natural drying, the samples were treated by plasma electrolytic oxidation in an phosphate electrolytic solution. All chemical reagents were analytically pure and the solution temperature was controlled to below $40{ }^{\circ} \mathrm{C}$ by adjusting the flowing velocity of the cooling water. In the experimental process, the pulse frequency and duration ratio was $366 \mathrm{~Hz}$ and $10 \%$, respectively, and the current density, voltage and duration time were in the ranges from $3 \mathrm{~A} / \mathrm{dm}^{2}$ to $12 \mathrm{~A} / \mathrm{dm}^{2}, 200 \mathrm{~V}$ to $500 \mathrm{~V}$, and $10 \mathrm{~min}$ to $40 \mathrm{~min}$, respectively.

The phase was characterized by X-ray diffraction meter with $\mathrm{Ni}$ filtered $\mathrm{Cu} \mathrm{K} \alpha$ radiation $(\lambda=0.15418 \mathrm{~nm})$ and scintillation detector within $2 \theta$ in the range $25^{\circ} \sim 85^{\circ}$. The microstructures were observed by scanning electron microscopy (SEM). Coatings thicknesses were measured by an eddy current method. The film-substrate cohesion test was performed with scratch tester at different loads $(50,60$, $70,80,90,100 \mathrm{~N})$. During the thermal shock resistance experiment, the sample was heated to a fixed temperature $\left(550^{\circ} \mathrm{C}\right)$ in the muffle furnace, and then immersed in room temperature water until the sample was cooled down completely; after many times the surface was analyzed. As tritium is difficult to get by conventional means and it is highly toxic, the coatings tritium permeability was tested by deuterium permeation measurement equipment.

\section{Results and Discussion}

\subsection{Effects of different parameters on coatings}

\subsubsection{Phase structure of coatings}

The effects of different current densities and voltages on phase compositions are given in Fig.1 and Fig.2, respectively. The diffraction peaks corresponding to the angles $43.5^{\circ}, 35.1^{\circ}, 57.5^{\circ}$, and $68.3^{\circ}$ show the presence of $\alpha-\mathrm{Al}_{2} \mathrm{O}_{3}$ phase in both figures. meanwhile the diffraction peaks corresponding to the angles $66.7^{\circ}, 45.7^{\circ}, 37.5^{\circ}$, and $39.4^{\circ}$ show the presence of $\gamma-\mathrm{Al}_{2} \mathrm{O}_{3}$ phase, and the diffraction peaks corresponding to the angles $38.5^{\circ}, 44.8^{\circ}$, $65.2^{\circ}, 78.2^{\circ}$, and $82.5^{\circ}$ show the presence of $\mathrm{Al}$ phase. $\alpha-\mathrm{Al}_{2} \mathrm{O}_{3}$ is a high temperature phase in the alumina family, which can only be obtained above $1200{ }^{\circ} \mathrm{C}^{[9]}$. During PEO process, the great heat releases because of instant discharging breakdown, it gets to high temperature(above $1200{ }^{\circ} \mathrm{C}$ ) and then stimulates the generation of $\alpha$ phase ${ }^{[10]}$. When the reaction is insufficient, the molten $\mathrm{Al}$ produced by local reaction high temperature is easily clad by $\mathrm{Al}_{2} \mathrm{O}_{3}$ coatings, and thus there is $\mathrm{Al}$ phase in XRD results ${ }^{[11]}$.

As seen from Fig.1, $\mathrm{Al}_{2} \mathrm{O}_{3}$ phase diffraction peaks are more pronounced and the crystalline becomes well with current density changing from $3 \mathrm{~A} / \mathrm{dm}^{2}$ to $9 \mathrm{~A} / \mathrm{dm}^{2}$; meanwhile $\mathrm{Al}$ phase diffraction peaks are weaker. But when the current density increases from $9 \mathrm{~A} / \mathrm{dm}^{2}$ to $12 \mathrm{~A} / \mathrm{dm}^{2}$, there is no significant change in the diffraction peaks. With current density increasing in a certain range, the power increases greatly and PEO reaction becomes sufficient gradually, the less molten $\mathrm{Al}$ is clad by $\mathrm{Al}_{2} \mathrm{O}_{3}$ coatings. That is to say the driving force for the transformation of $\mathrm{Al} \rightarrow \mathrm{Al}_{2} \mathrm{O}_{3}$ is big in a certain range, so the relative content of $\mathrm{Al}$ phase decreases and $\mathrm{Al}_{2} \mathrm{O}_{3}$ phase increases obviously. With current density changing from $3 \mathrm{~A} / \mathrm{dm}^{2}$ to $12 \mathrm{~A} / \mathrm{dm}^{2}$, the value $\mathrm{P}$ (ratio of $\alpha-\mathrm{Al}_{2} \mathrm{O}_{3} / \gamma-\mathrm{Al}_{2} \mathrm{O}_{3}$ ) increases slowly, which changes from 0.41 to 0.47 according to the Jade analysis. That is to say the driving force for the transformation of $\gamma-\mathrm{Al}_{2} \mathrm{O}_{3} \rightarrow \alpha-\mathrm{Al}_{2} \mathrm{O}_{3}$ is little.

As seen from Fig.2, the $\alpha-\mathrm{Al}_{2} \mathrm{O}_{3}$ phase diffraction peaks are more pronounced, and $\gamma-\mathrm{Al}_{2} \mathrm{O}_{3}$ phase diffraction peaks are weaker with the voltage change from $200 \mathrm{~V}$ to $400 \mathrm{~V}$; meanwhile Al phase diffraction peaks change less. But when the voltage increases from $400 \mathrm{~V}$ to $500 \mathrm{~V}$, no significant change occurs in the diffraction peaks. With the voltage increasing in a certain range, the alumina coatings are generated in the strong electric and magnetic field on the sample surfaces. Then the instant discharging breakdown is stronger, great heat is released, and the temperature becomes higher within a short time and increases to above $1200^{\circ} \mathrm{C}$. That is to say, the driving force 
for the transformation of $\gamma-\mathrm{Al}_{2} \mathrm{O}_{3} \rightarrow \alpha-\mathrm{Al}_{2} \mathrm{O}_{3}$ is big in a certain range, so the relative content of $\alpha-\mathrm{Al}_{2} \mathrm{O}_{3}$ phase increases in the whole $\mathrm{Al}_{2} \mathrm{O}_{3}$ coatings; meanwhile the driving force for the transformation of $\mathrm{Al} \rightarrow \mathrm{Al}_{2} \mathrm{O}_{3}$ is little. With the voltage changing from $200 \mathrm{~V}$ to $500 \mathrm{~V}$, the value $P$ increases greatly, which changes from 0.37 to 1.68 according to the Jade analysis.

From the above, it can be seen that the higher current density propels the transformation of $\mathrm{Al} \rightarrow \mathrm{Al}_{2} \mathrm{O}_{3}$ and the higher voltage propels the transformation of $\gamma-\mathrm{Al}_{2} \mathrm{O}_{3} \rightarrow$ $\alpha-\mathrm{Al}_{2} \mathrm{O}_{3}$. The maximum value $P$ is 1.68 and the $\alpha-\mathrm{Al}_{2} \mathrm{O}_{3}$ is about $63 \%$ in the whole $\mathrm{Al}_{2} \mathrm{O}_{3}$ coatings.

\subsubsection{Surface morphology of coatings}

During PEO process, the coatings are broken down by the instant discharging and then the micro discharge channels are produced, so the coating surfaces become porous. Meanwhile some alumina coatings are melted owing to the high temperature during the reaction, then these pores are filled with the melt and disappear on the coating surfaces ${ }^{[12]}$. As tritium is easy to permeate coatings through these pores, which seriously affects the tritium permeability, and the quality of coating surface depends on the pore size and its quantity. The effects of different current densities and voltages on coating surfaces are shown in Fig.3 and Fig.4, respectively.

As can be seen from Fig.3, the sizes of the pores are small when current density is $3 \mathrm{~A} / \mathrm{dm}^{2}$. With the current density increasing to $6 \mathrm{~A} / \mathrm{dm}^{2}$, the power increases, the alumina coating is melted more and the instant discharging is

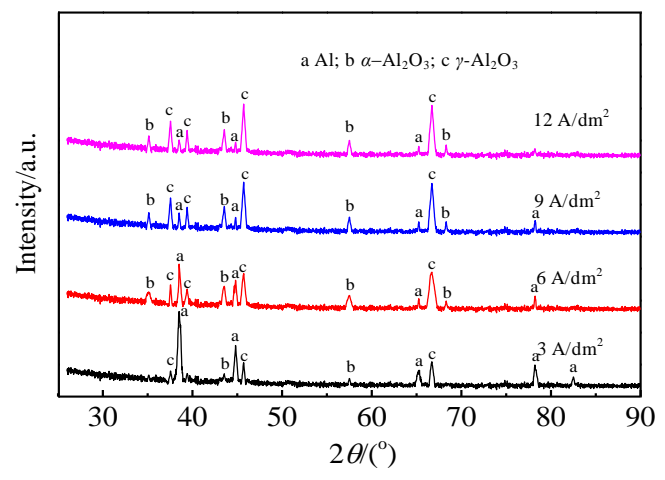

Fig.1 XRD patterns of coatings obtained at different current densities

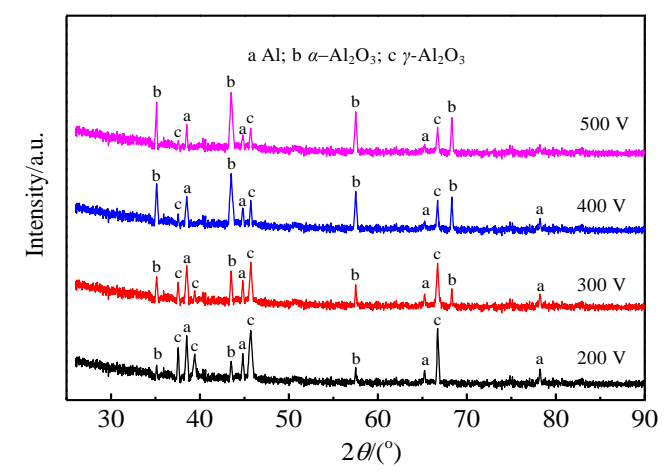

Fig.2 XRD patterns of coatings obtained at different voltages stronger, the instant discharging phenomenon is more serious than that of the alumina coating melting so the pore sizes become bigger and the quantity of pores increases ${ }^{[13]}$. When the current density is $9 \mathrm{~A} / \mathrm{dm}^{2}$, as the alumina coating melting phenomenon is more serious than that of the instant discharging, then more pores are filled, these pore sizes become the smallest and the quantity of pores is minimum. With the current density further increasing, the instant discharging phenomenon is more serious than that of the alumina coating melting again, and then the pores are unable to be filled with the melt, so the pore sizes become bigger again. It can be seen that a proper current density can make the surface morphology good.

As can be seen from Fig.4, under the conditions of $200 \mathrm{~V}$, the voltage is too low to break down the coatings and the micro discharge channels are not completely formed; thus the typical pores do not appear ${ }^{[14]}$. At $300 \mathrm{~V}$, when the micro discharge channels are formed, the typical pores appear on the surfaces with small sizes and regular shape, and their quantity is less. With the voltage increasing, the instant discharging becomes stronger, and the alumina coating is melted more. But the alumina coatings melting phenomenon is not more serious than that of the instant discharging so pores sizes increase quickly, but the quantity is less, and the quality of coating surface become worse.

As can be seen from Fig.5c, as PEO duration time is longer, the coating thickness is increased (the coating thickness results will be discussed in the following), the coatings are more difficult to break down until the voltage is high; at that time the instant discharging is stronger, and big size pores with less quantity appear on the coating surface, and the quality of coating surface is worse ${ }^{[15]}$.

From the above, it can be seen that current density, voltage and duration time can change the surface morphology of the coating. With increasing the voltage and duration time, the pore size becomes bigger and the quantity decreases so the surface morphology becomes worse. As current density increases to a proper value $\left(9 \mathrm{~A} / \mathrm{dm}^{2}\right)$, the surface morphology becomes good.

\subsubsection{Thickness of coatings}

As can be seen from Fig.5a under a fixed duration time of $30 \mathrm{~min}$ when current densities are 3,6,9 and $12 \mathrm{~A} / \mathrm{dm}^{2}$, the average coatings thickness are $6,10,18$ and $21 \mu \mathrm{m}$, respectively.

As can be seen from Fig.5b, under a fixed duration time of $30 \mathrm{~min}$, when voltages are 200, 300, 400, $500 \mathrm{~V}$, the average thicknesses of coatings are 3, 6, 12 and $16 \mu \mathrm{m}$, respectively.

As can be seen from Fig.5c, at 6 A, 300 V, when duration time increases, the coating thickness increases, but the growth rate gets slower.

From the above, it can be seen that the average coating thickness increases with increasing the current density, 

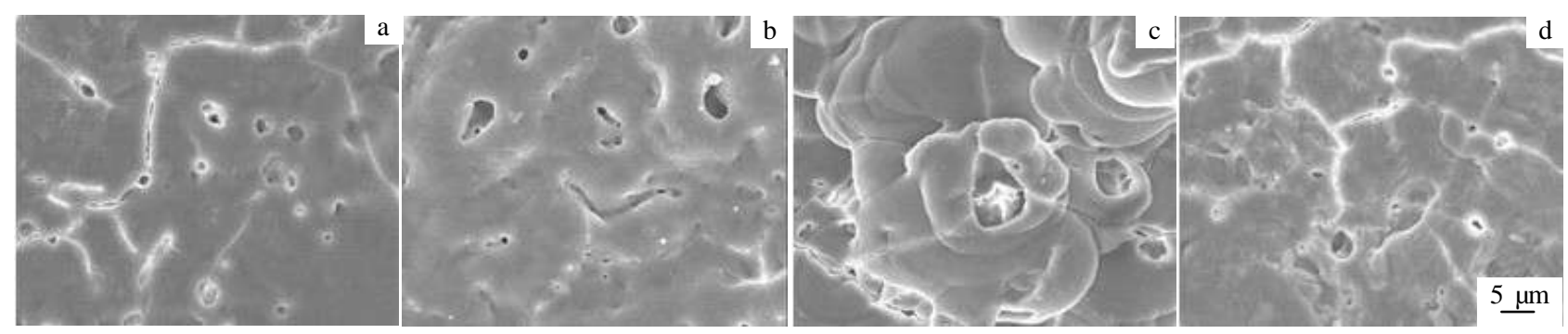

Fig.3 SEM images of surface morphologies of coatings obtained at different current densities: (a) $3 \mathrm{~A} / \mathrm{dm}^{2}$, (b) $6 \mathrm{~A} / \mathrm{dm}^{2}$, (c) 9 A/dm ${ }^{2}$, and (d) $12 \mathrm{~A} / \mathrm{dm}^{2}$
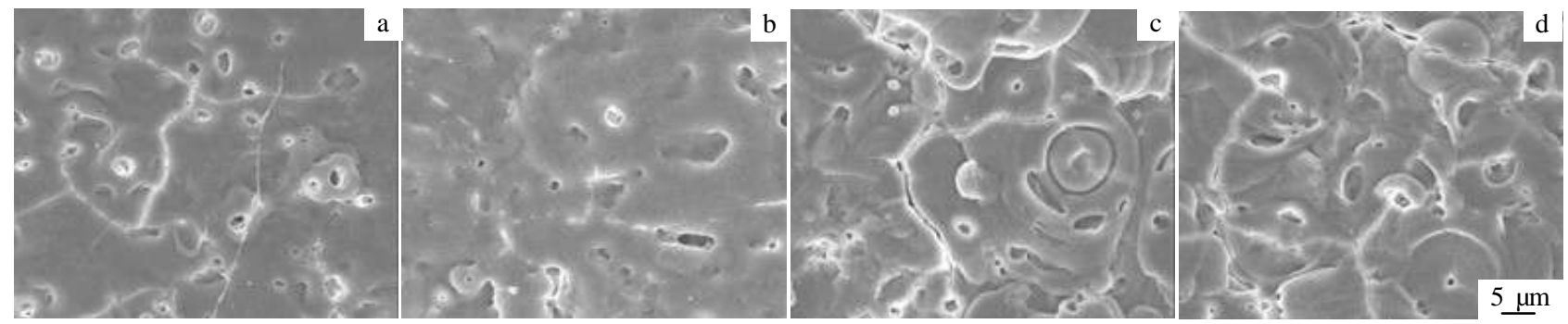

Fig.4 SEM images of surface morphologies of coatings obtained at different voltages: (a) $200 \mathrm{~V}$, (b) $300 \mathrm{~V}$, (c) $400 \mathrm{~V}$, and (d) $500 \mathrm{~V}$
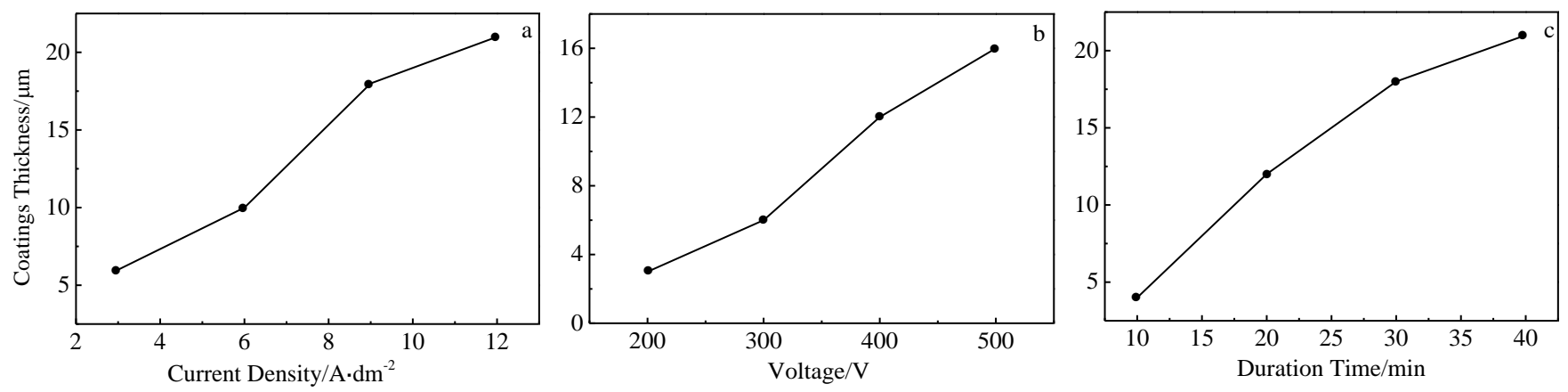

Fig.5 Thicknesses of coatings of different parameters: (a) current density (from $3 \mathrm{~A} / \mathrm{dm}^{2}$ to $12 \mathrm{~A} / \mathrm{dm}^{2}$ ); (b) voltage (from 200 to $500 \mathrm{~V}$ ); (c) duration time (from $10 \mathrm{~min}$ to $40 \mathrm{~min}$ )

voltage and duration time.

\subsection{Properties of coatings}

According to the above experimental results, a group of technological parameters, as shown in Table 1, were used to prepare coatings on stainless steel substrates, then their properties were evaluated by following tests, and finally the coating samples prepared by the optimized parameters resulting from property evaluation were obtained.

\subsubsection{Scratch adhesion}

The load, at which the sample presents film peeling, is considered as the critical load of a coating. The critical load results for different samples are given in Fig.6. The minimum critical load is observed for the coating prepared at $6 \mathrm{~A} / \mathrm{dm}^{2}$, $300 \mathrm{~V}$ and $20 \mathrm{~min}$ and the maximum critical load is observed for the coating prepared at $9 \mathrm{~A} / \mathrm{dm}^{2}, 400 \mathrm{~V}$ and $30 \mathrm{~min}$.

2.2.2 Thermal shock resistance
As the tritium permeation barrier coatings work under thermal-cold cycling condition, which leads to thermal stress in the coatings and the coatings often break and peel off, it is necessary to evaluate the coatings thermal shock resistance.

After 200 times tests, the coating prepared at $6 \mathrm{~A} / \mathrm{dm}^{2}$, $300 \mathrm{~V}, 20 \mathrm{~min}$ and $9 \mathrm{~A} / \mathrm{dm}^{2}, 400 \mathrm{~V}, 30 \mathrm{~min}$ present film peeling and the one prepared at $6 \mathrm{~A} / \mathrm{dm}^{2}, 400 \mathrm{~V}, 20 \mathrm{~min}$ presents lots of big size thermal corrosion pores at visual inspection. As can be seen from Fig.7a, the coating prepared at $6 \mathrm{~A} / \mathrm{dm}^{2}, 300 \mathrm{~V}, 30 \mathrm{~min}$ is in good state without any film peeling and thermal corrosion pores by SEM analysis. After 280 times test, the result of the coatings prepared at $6 \mathrm{~A} / \mathrm{dm}^{2}, 300 \mathrm{~V}, 30 \mathrm{~min}$ is shown in Fig.7b, the coating exhibits no obvious change on the surface compared with that after 100 times test. 
Table 1 Parameters of test samples

\begin{tabular}{ccc}
\hline Voltage/V & Current density $/ \mathrm{A} \cdot \mathrm{dm}^{-2}$ & Duration time/min \\
\hline 300 & 6 & 20 \\
400 & 9 & 20 \\
300 & 6 & 30 \\
400 & 9 & 30 \\
\hline
\end{tabular}

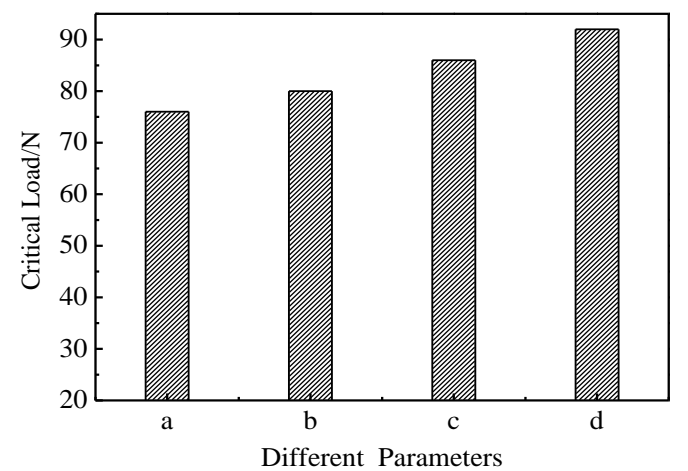

Fig.6 Critical loads on the coatings produced for different parameters: (a) $6 \mathrm{~A} / \mathrm{dm}^{2}, 300 \mathrm{~V}, 20 \mathrm{~min}$; (b) $9 \mathrm{~A} / \mathrm{dm}^{2}, 400$ $\mathrm{V}, 20 \mathrm{~min}$; (c) $6 \mathrm{~A} / \mathrm{dm}^{2}, 300 \mathrm{~V}, 30 \mathrm{~min}$; (d) $9 \mathrm{~A} / \mathrm{dm}^{2}, 400 \mathrm{~V}$, $30 \mathrm{~min}$

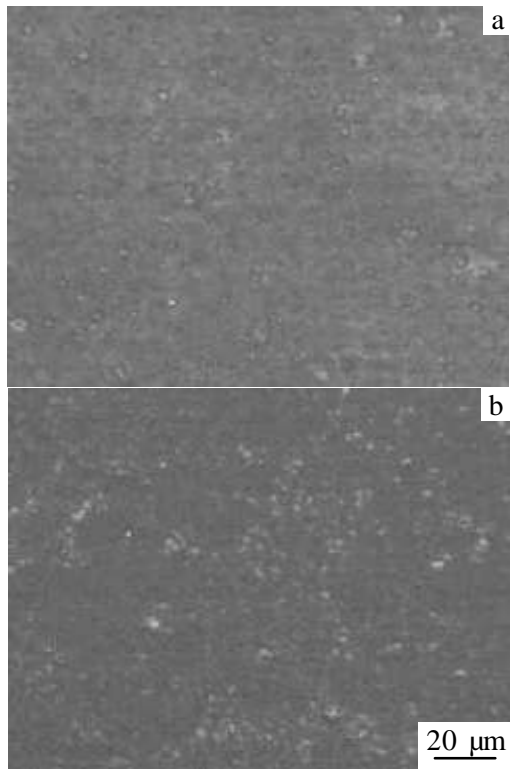

Fig.7 SEM images of surface morphology of coatings (prepared at $6 \mathrm{~A} / \mathrm{dm}^{2}, 300 \mathrm{~V}, 30 \mathrm{~min}$ ) after thermal shock resistance test: (a) 200 times and (b) 280 times

\subsubsection{Tritium permeability}

The deuterium permeation measurement equipment is shown in Fig.8; it consists of sample permeation chamber, high vacuum permeation analysis system, high vacuum system, deuterium-charging system and quadruple mass

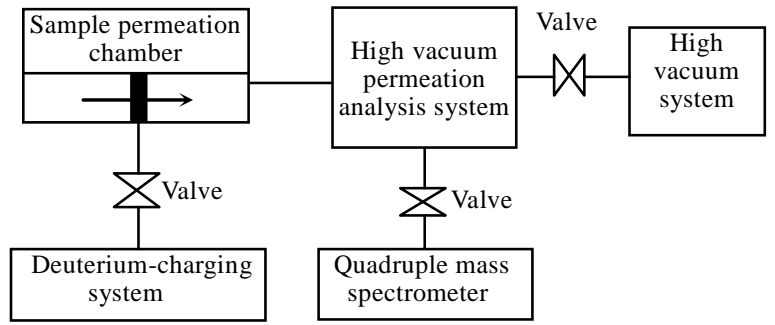

Fig.8 Deuterium permeation measurement equipment

spectrometer $^{[16]}$. The quadrupole mass spectrometer can obtain the permeation fluxes of deuterium at different temperatures, and after testing the sample thickness and basal area, the permeability is obtained according to the Fick law and Sievert law ${ }^{[17]}$. The permeability is calculated with $\varphi$ :

$$
\varphi=\frac{J L}{S P}
$$

Where, $J$ is steady state permeation flux, $L$ is sample thickness, $S$ is sample basal area, and $P$ is deuterium pressure

The coated sample, prepared at $6 \mathrm{~A} / \mathrm{dm}^{2}, 300 \mathrm{~V}, 30 \mathrm{~min}$ was selected and tested by deuterium permeation measurement equipment because of its high bonding strength and thermal shock resistance, and an uncoated sample was tested for comparison. The deuterium PRF is 1930 at $500{ }^{\circ} \mathrm{C}$, which changes to 1460 at $600{ }^{\circ} \mathrm{C}$, and deceases to 1150 at $700{ }^{\circ} \mathrm{C}$.

\section{Conclusions}

1) The current density and the voltage can change the phase structure of a coating. High current density propels the transformation of $\mathrm{Al} \rightarrow \mathrm{Al}_{2} \mathrm{O}_{3}$ and high voltage propels the transformation of $\gamma-\mathrm{Al}_{2} \mathrm{O}_{3} \rightarrow \alpha-\mathrm{Al}_{2} \mathrm{O}_{3}$.

2) With increasing of the voltage and duration time, the pore size becomes bigger and the quantity becomes less so surface morphology becomes worse. With current density increases to a proper value $\left(9 \mathrm{~A} / \mathrm{dm}^{2}\right)$, the surface morphology is good.

3) After a series of tests, the coating prepared at $6 \mathrm{~A} / \mathrm{dm}^{2}$, $300 \mathrm{~V}, 30 \mathrm{~min}$ has the good performances with a strong film-substrate cohesion, a good thermal shock resistance, and the tritium permeation resistance of the coated sample is much improved with 3 orders of magnitude higher than the $316 \mathrm{~L}$ stainless steel bulk.

\section{References}

1 Perujo A, Forcey K S. Fusion Engineering and Design[J], 1995, 28(2): 252

2 Hollenberg G W, Simonen E P, Kalinin G et al. Fusion Engineering and Design [J], 1995, 28(2): 190 
3 Wang P X, Liu J, Wang Y et al. Surface and Coatings Technology[J], 2000, 128-129(1): 99

4 Lee Y K, Lee K, Jung T. Electrochem Commun[J], 2008, 10: 1716

5 Fazio C, Stein-Fechner K, Serra E et al. Journal of Nuclear Materials[J], 1999, 273: 233

6 Glas Brener H, Konys J, Voss Z et al. Journal of Nuclear Materials[J], 2002, 307-311: 1360

7 Benamati G, Chabrol C, Perujo A et al. Journal of Nuclear Materials[J], 1999, 271-272: 391

8 Aiello A, Ciampichetti A, Benamati G. Journal of Nuclear Materials[J], 2004, 329-333(2): 1398

9 Zhang Ligong, Zhao Guimei, Lai Xiaoming. Advanced Materials Research[J], 2011, 239-242: 667
10 Deepthi Sankar, Shalumon K T, Chennazhi K P et al. Tissue Engineering: Part A [J], 2014, 20: 11

11 Rudnev V S. Surf Coat Tech [J], 2013, 235: 134

12 Chen F, Zhou H, Yao B et al. Surf Coat Tech [J], 2007, 201: 4905

13 Jin F, Tong H, Li J et al. Surf Coat Tech [J], 2006, 201: 292

14 Xin S G, Song L X, Zhao R G et al. Mater Chem Phys[J], 2006, 97: 132

15 Sundararajan G, Rama K L. Surf Coat Tech[J], 2003, 167 : 269

16 Benamati G, Chabrol C, Perujo A et al. J Nucl Mater [J], 1999, 271-272: 391

17 Forcey K S, Ross D K. J Nucl Mater [J], 1991, 182: 36

\section{微弧氧化制备氧化铝阻氞涂层的研究}

冯 军 ${ }^{1,2}$, 但 敏 $^{1}$, 金凡亚 ${ }^{1}$, 陈美艳 ${ }^{1}$, 沈丽如 $^{1}$, 童洪辉 ${ }^{1}$, 张桂凯 ${ }^{3}$

(1. 核工业西南物理研究院, 四川 成都 610041)

(2. 南华大学, 湖南 衡阳 421001)

(3. 中国工程物理研究院, 四川 绵阳 621907)

摘 要: 采用微弧氧化技术在316L不锈钢基体上制备了氧化铝阻㲴涂层, 利用XRD、SEM、浴流法对涂层进行了相结构、表面形貌、 膜厚的分析, 并进行了划痕实验、抗热震性能及阻気性能测试。结果表明: 相结构、表面形貌、膜厚受到微弧氧化电流密度、电压、反 应时间的影响。其中, 电流密度、电压都能改变涂层相结构, 较高电流密度将促进 $\mathrm{Al} \rightarrow \mathrm{Al}_{2} \mathrm{O}_{3}$ 的形成, 而较高电压将促进 $\gamma-\mathrm{Al}_{2} \mathrm{O}_{3} \rightarrow \alpha-\mathrm{Al}_{2} \mathrm{O}_{3}$ 的相变。提高电压、反应时间, 涂层表面放电孔洞将变大从而影响表面质量; 最佳电流密度为 $9 \mathrm{~A} / \mathrm{dm}^{2}$, 此时表面质量较好。通过性能 测试及综合分析, 最佳工艺参数为 $6 \mathrm{~A} / \mathrm{dm}^{2} 、 300 \mathrm{~V} 、 30 \mathrm{~min}$, 膜基结合力、抗热震较好, 能使 $316 \mathrm{~L}$ 不锈钢的気渗透率降低 3 个数量级。 关键词: 氧化铝涂层; 阻気; 微弧氧化

作者简介: 冯 军, 男, 1979 年生, 博士生, 核工业西南物理研究院, 四川 成都 610041, 电话: 028-82820988, E-mail: speedfjkang@ 163.com 